Katherine Mansfield and Continental Europe 
Also by Janka Kascakova

MIDDLE-EARTH AND BEYOND: Essays on the World of J.R.R. Tolkien (ed.)

DOES IT REALLY MEAN THAT: Interpreting the Literary Ambiguous (ed.)

Also by Gerri Kimber

EDINBURGH EDITION OF THE COLLECTED WORKS

OF KATHERINE MANSFIELD

KATHERINE MANSFIELD: The View from France

Katherine Mansfield and the Art of the Short Story 


\section{Katherine Mansfield and Continental Europe}

\section{Connections and Influences}

Edited by

Janka Kascakova

Catholic University in Ružomberok, Slovakia

and

Gerri Kimber

University of Northampton, UK

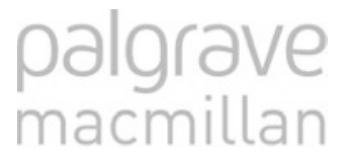




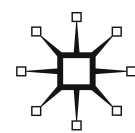

Introduction, selection and editorial matter @ Janka Kascakova and

Gerri Kimber 2015

Individual chapters (C) Contributors 2015

Softcover reprint of the hardcover 1st edition 2015 978-1-137-42996-4

All rights reserved. No reproduction, copy or transmission of this publication may be made without written permission.

No portion of this publication may be reproduced, copied or transmitted save with written permission or in accordance with the provisions of the Copyright, Designs and Patents Act 1988, or under the terms of any licence permitting limited copying issued by the Copyright Licensing Agency, Saffron House, 6-10 Kirby Street, London EC1N 8TS.

Any person who does any unauthorized act in relation to this publication may be liable to criminal prosecution and civil claims for damages.

The authors have asserted their rights to be identified as the authors of this work in accordance with the Copyright, Designs and Patents Act 1988.

First published 2015 by

PALGRAVE MACMILLAN

Palgrave Macmillan in the UK is an imprint of Macmillan Publishers Limited, registered in England, company number 785998, of Houndsmills,Basingstoke, Hampshire,RG21 6XS

Palgrave Macmillan in the US is a division of St Martin's Press LLC, 175 Fifth Avenue, New York, NY 10010.

Palgrave is the global academic imprint of the above companies and has companies and representatives throughout the world.

Palgrave ${ }^{\circledR}$ and Macmillan ${ }^{\circledR}$ are registered trademarks in the United States, the United Kingdom, Europe and other countries.

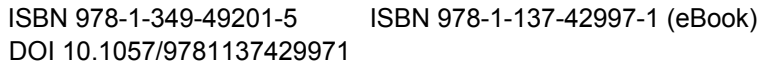

This book is printed on paper suitable for recycling and made from fully managed and sustained forest sources. Logging, pulping and manufacturing processes are expected to conform to the environmental regulations of the country of origin.

A catalogue record for this book is available from the British Library.

Library of Congress Cataloging-in-Publication Data

Katherine Mansfield and continental Europe: connections and influences / edited by Janka Kascakova, Gerri Kimber.

pages $\mathrm{cm}$

Includes bibliographical references and index.

1. Mansfield, Katherine, 1888-1923-Criticism and interpretation.

2. Mansfield, Katherine, 1888-1923-Appreciation-Europe.

I. Kascakova, Janka, editor. II. Kimber, Gerri, editor.

PR9639.3.M258Z7323 2015

$823 \cdot .912-\mathrm{dc} 23$

2014038550

Typeset by MPS Limited, Chennai, India. 


\section{Contents}

List of Illustrations vii

Acknowledgements viii

Notes on Contributors ix

1 Introduction 1

Janka Kascakova and Gerri Kimber

I Reception

2 An 'utterly concrete and yet impalpable' Art: The Early Reception of Katherine Mansfield in Italy (1922-1952) 7 Maurizio Ascari

3 Katherine Mansfield's Early Translations and Reception in Hungary

Nóra Séllei

4 'My dear, incomparable, priceless, Kateřina Mansfieldová' - The Reception and Translations

of Katherine Mansfield in (the former) Czechoslovakia Janka Kascakova

\section{Poland and Germany}

5 'That Pole outside our door': Floryan Sobieniowski and Katherine Mansfield

Gerri Kimber

6 Katherine Mansfield and Stanisław

Wyspiański - Meeting Points

Mirostawa Kubasiewicz

7 Katherine Mansfield's Germany: 'these pine trees provide most suitable accompaniment for a trombone!'

Delia da Sousa Correa

\section{Connections with Other Authors}

8 'Liaisons continentales': Katherine Mansfield,

S. S. Koteliansky and the Art of Modernist Translation

Claire Davison 
9 'There is always the other side, always': Katherine Mansfield's and Jean Rhys's Travellers in Europe Angela Smith

10 The Beauchamp Connection Jennifer Walker

IV Identity, the 'Self' and 'Home'

11 'How can one look the part and not be the part?': National Identity in Mansfield's 'An Indiscreet Journey', 'Je ne parle pas français', and 'Miss Brill' Erika Baldt

12 'Strange flower, half opened': Katherine Mansfield and the Flowering of 'the Self'

Kathryn Simpson

13 The 'dream of roots and the mirage of the journey': Writing as Homeland in Katherine Mansfield

Patricia Moran

\section{Reassessing the Fiction}

14 Katherine Mansfield's Stories 1909-1914: The Child and the 'Childish' Janet Wilson

15 Katherine Mansfield and the Fictions of Continental Europe

C. K. Stead 


\section{List of Illustrations}

Frontispiece Katherine Mansfield's passport. Alexander Turnbull Library, Wellington, New Zealand, Murry

Family Collection, MS-Papers-11326-070

xii

6.1 Stanisław Wyspiański. Self-portrait (1902), pastel. (c) Copyright Ligier Piotr/Muzeum Narodowe w Warszawie

6.2 Stanisław Wyspiański. God the Father - project of a stained glass for the Church of St. Francis in Kraków (1897), tempera, canvas, pastel. From the collection of the National Museum in Kraków. (c) Copyright Pracownia Fotograficzna Muzeum Narodowego w Krakowie

6.3 Stanisław Wyspiański. Roses - fragment of a polychrome for the Church of St Francis in Kraków (1895-6), pastel. From the collection of the National Museum in Kraków. (c) Copyright Pracownia Fotograficzna Muzeum Narodowego w Krakowie

6.4 Stanisław Wyspiański. A Girl in a Regional Dress (1901), pastel. (C) Copyright Wilczyński Krzysztof/Muzeum

Narodowe w Warszawie

6.5 Stanisław Wyspiański. Portrait of Two Girls (1895), pastel. (c) Copyright by Wilczyński Krzysztof/Muzeum Narodowe w Warszawie 


\section{Acknowledgements}

The images from Katherine Mansfield's passport on the front cover and frontispiece are reproduced with kind permission of the Alexander Turnbull Library, Wellington, New Zealand (Katherine Mansfield's passport, Murry Family Collection, MS-Papers-11326-070). The reproductions of works by Stanisław Wyspiański used to illustrate the essay by Mirosława Kubasiewicz are included with kind permission of the National Museum in Krakow and the National Museum in Warsaw. For permission to quote from manuscripts, the editors would like to thank the Alexander Turnbull Library, Wellington, New Zealand, and the University of Tulsa, McFarlin Library, Department of Special Collections.

The editors would like to thank Paula Kennedy and Peter Cary from Palgrave Macmillan for their support and help with this project, together with the invaluable assistance of our copy-editor, Linda Auld, Delia da Sousa Correa for invaluable editorial assistance, Claire Davison, and the members of the Katherine Mansfield Society for making every event an unforgettable occasion. The list would be incomplete without a special thanks to our families whose generous support enables us to do what we love. 


\section{Notes on Contributors}

Maurizio Ascari is a Senior Lecturer in English at the University of Bologna. His recent publications include books and essays on crime fiction (A Counter-History of Crime Fiction, 2007), transcultural literature (Literature of the Global Age, 2011) and inter-art exchanges (Cinema and the Imagination in Katherine Mansfield's Writing, 2014). He has also edited and translated works by Henry James, Katherine Mansfield, William Faulkner, Jack London and Wilkie Collins.

Erika Baldt is an English Lecturer at Burlington County College in New Jersey where she teaches composition and literature. She earned a PhD in English and Comparative Literature from Goldsmiths, University of London with a thesis on the work of Virginia Woolf and Katherine Mansfield, and their contemporaries of the Harlem Renaissance, Jessie Fauset and Nella Larsen. She has published essays on the work of Fauset, Mansfield, Woolf and Vita Sackville-West. Her research interests include Anglo-American modernism and cosmopolitanism, as well as service learning and its integration into a community college environment.

Delia da Sousa Correa is Senior Lecturer in English at the Open University. She studied at the Universities of Canterbury (NZ), London and Oxford. She is general editor of Katherine Mansfield Studies (Edinburgh University Press) and has written numerous research essays and teaching materials on Mansfield. Other publications include George Eliot, Music and Victorian Culture (2003) and, as editor, The NineteenthCentury Novel: Realisms (2000), Phrase and Subject: Studies in Literature and Music (2006), and The Handbook to Literary Research, edited with W.R. Owens (2010). She is editor of the forthcoming Edinburgh Companion to Literature and Music.

Claire Davison is Professor of Modernist Literature at the Université Sorbonne Nouvelle - Paris III, and also the current Chair of the French Virginia Woolf Society. Her research and recent publications bear on creative collaborations in trans-medial and trans-linguistic modernist literature, with two specific points of focus: the modernist reception of Russian literature through co-translation, and musico-literary radio works. Her publications include Translation as Collaboration: Virginia Woolf, Katherine Mansfield and S. S. Koteliansky (2014). 
Janka Kascakova is a Senior Lecturer in English at Catholic University in Ružomberok, Slovakia. Her research centres on modernism and the modernist short story, especially the works of Katherine Mansfield, as well as fantasy literature, chiefly the works of J. R. R. Tolkien. With Kathleen Dubs, she is co-editor of Middle-earth and Beyond: Essays on the World of J.R.R. Tolkien (2010) and Does it Really Mean That: Interpreting the Literary Ambiguous (2011). She has published numerous articles on Katherine Mansfield and her most recent publication is the first book translation of Katherine Mansfield's short stories into Slovak (2013).

Gerri Kimber is a Senior Lecturer in English at the University of Northampton. She is co-editor of the annual yearbook Katherine Mansfield Studies, and is the deviser and Series Editor of the four-volume Edinburgh Edition of the Collected Works of Katherine Mansfield (2012-15). She is the author of Katherine Mansfield: The Early Years (forthcoming, 2015), Katherine Mansfield: The View from France (2008), and A Literary Modernist: Katherine Mansfield and the Art of the Short Story (2008). Gerri is Chair of the International Katherine Mansfield Society and has co-organised numerous international Mansfield conferences and events. In 2014, Gerri was one of three nominees for the title UK New Zealander of the Year, for her services to New Zealand culture.

Mirosława Kubasiewicz is a lecturer at the University of Zielona Góra, Poland, where she teaches courses in the history of English literature. Her research interests focus on connections between literature and philosophy, as well as the work of Katherine Mansfield and other women writers. Recently she has transcribed Mansfield's translation of Stanisław Wyspiański's play The Judges, collected in volume 3 of The Edinburgh Edition of the Collected Works of Katherine Mansfield: The Poetry and Critical Writings of Katherine Mansfield, edited by Gerri Kimber and Angela Smith (2014).

Patricia Moran was formerly Professor of English at the University of California, Davis, and now teaches at the University of Limerick in Ireland. She is the author of Word of Mouth: Body/Language in Katherine Mansfield and Virginia Woolf (1996); Virginia Woolf, Jean Rhys, and the Aesthetics of Trauma (2007); co-editor of Scenes of the Apple: Food and the Female Body in 19th- and 20th-Century Women's Writing (2003) and The Female Face of Shame (2013). She is co-editing a volume of essays on Jean Rhys for Edinburgh University Press and completing a study of female modernists and shame. 
Nóra Séllei is Professor of English at the University of Debrecen, Hungary, and at Catholic University in Ružomberok, Slovakia. She gained her PhD (1996) and habilitation (2001) from the University of Debrecen, and DSc from the Hungarian Academy (2013). Her main fields of teaching and research are gender studies, feminist literary theory, and 19th and 20th-century women writers. Her publications include five monographs, seven edited volumes and about eighty scholarly articles. She was the series editor of the Hungarian feminist series Artemis Books, and is the Hungarian translator of Jean Rhys's Smile Please (2001), Virginia Woolf's Moments of Being (1999) and Three Guineas (2006).

Kathryn Simpson is Senior Lecturer in English at Cardiff Metropolitan University, UK. Her main research interests are in modernist writing, particularly the work of Virginia Woolf and Katherine Mansfield. Other research interests include the work of contemporary writers, Sarah Waters and David Mitchell. She is author of Gifts, Markets and Economies of Desire in Virginia Woolf (2008).

Angela Smith is an Emeritus Professor in English at the University of Stirling in Scotland. Her books include East African Writing in English (1989), Katherine Mansfield and Virginia Woolf: A Public of Two (1999), and Katherine Mansfield: A Literary Life (2000). She has edited Jean Rhys's Wide Sargasso Sea for Penguin (1997), and Katherine Mansfield Selected Stories for Oxford World's Classics (2002). She is a vice-president of the Katherine Mansfield Society and the editor, with Gerri Kimber, of volume 3 of the Edinburgh Edition of Mansfield's Collected Works (2014).

C(hristian) K(arlson) Stead is Emeritus Professor of English at the University of Auckland, New Zealand. He is also known as a poet, novelist, short-story writer and critic. He is a Fellow of the Royal Society of Literature, has been Senior Visiting Fellow at St John's College Oxford, and was awarded an Honorary DLitt by the University of Bristol in 2001. He was awarded a CBE in 1995 for services to New Zealand Literature, and made a member of the Order of New Zealand (his country's highest honour) in 2007. He edited the Penguin (more recently Vintage) selection of Mansfield Letters and Journals, and his novel Mansfield was published by Harvill Secker in 2004.

Jennifer Walker began research for her biography of Elizabeth von Arnim, Elizabeth of the German Garden - A Literary Journey (2013), whilst living in Geneva, Switzerland. She has recently published articles on von Arnim in the Historic Gardens Review, and in The Journal of the 
H. G. Wells Society. In 2012, her papers on the relationship between von Arnim and Mansfield were presented at two conferences of the Katherine Mansfield Society. Her paper on von Arnim's association with T. J. Cobden-Sanderson was presented to the H. G. Wells Society in September 2013. Jennifer lives and works in Suffolk.

Janet Wilson is Professor of English and Postcolonial Studies at the University of Northampton. She has published widely on the literature and cinema of the white settler societies of Australia and New Zealand, including diaspora writing. Recent publications include the coedited volume, Katherine Mansfield and the (Post)colonial (2013). She was Chair of EACLALS from 2008 to 2011, is currently Vice-Chair of the Katherine Mansfield Society and the London-based New Zealand Studies Network (UK and Ireland), and co-editor of the Journal of Postcolonial Writing.

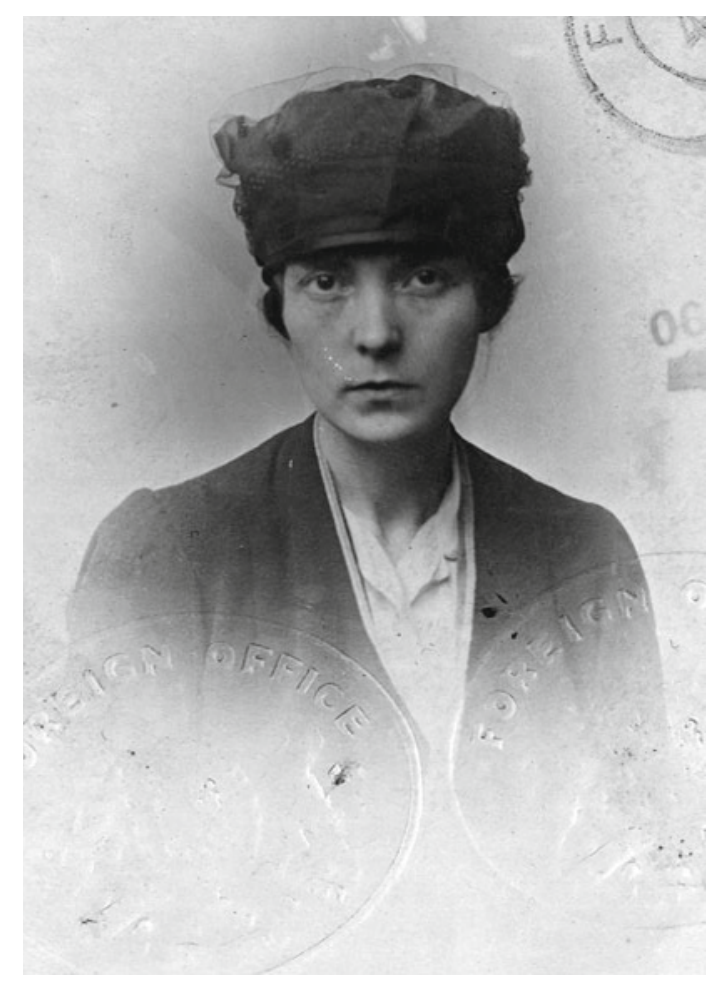

Frontispiece Katherine Mansfield's passport. Alexander Turnbull Library, Wellington, New Zealand, Murry Family Collection, MS-Papers-11326-070 